\title{
El cristocentrismo de san Agustín *
}

\section{El CRistocentrismo EN EL De TrinitATE}

Cuando Agustín planeó este Tratado De Trinitate, tenía prácticamente estructurada y fijada la doctrina de la presencia real de Cristo en la Iglesia, ya en el aspecto jerárquico, ya en la llamada «comunión de los santos». La doctrina trinitaria en el sentido tradicional, no parecía ofrecerle dificultad alguna. Trataba, pues, de explicar (re rationem) cómo la Trinidad es un sólo Dios, a la manera de los Padres Griegos, sin pretender rebasar su horizonte ni sus métodos. Quaeritur unitas Trinitatis, Patris et Filii et Spiritus Sancti (De Trinit. I, 3,5 PL 42,822). A ese sencillo planteamiento tradicional corresponden las dificultades tradicionales que ofrecía este dogma (Ibid., 4,7 y 5,8). Quizá el Santo no se daba cuenta de que al colocar al hombre en un régimen existencial y temporal (dispensatio temporalis), se planteaba una "Historia de la Salvación» que podría implicar muchos cambios. Con la doctrina tradicional podría convencer a los Donatistas sobre la presencia real y dinámica de Cristo en la Iglesia pero ya venían pisándole los talones otros herejes (Pelagianos) que presentaban nuevas dificultades.

En las Confesiones, Agustín presentaba a Cristo como único Camino, renunciando definitivamente a la mística neoplatónica. Sólo podemos llegar hasta Dios por medio de la fe y de la revelación, «por espejo y en enigma» y toda explicación dialéctica o racionalista del dogma cristiano deberá ajustarse estrictamente a esa revelación y a esa fe. Por eso ya en las Confessiones, el problema presentaba nuevos aspectos, ya que el hombre en principio está separado de Dios, aunque no del todo. Si el hombre está separado de Dios, y no puede por sí mismo llegar hasta Él, el Cristo-Camino ha de significar una

\footnotetext{
* Este artículo lo dejó así el padre Lope ya en los últimos momentos de su vida, pero, por su contenido, consideramos importante publicarlo aunque no pudiera ponerle ya finalmente el aparato crítico conveniente.
} 
«mediación» (Confess. X, 41, 66-70 PL 32, 807-810). Aunque brevemente, Agustín abría una nueva perspectiva. Es necesaria absolutamente una «mediación», pero ¿qué mediación? ¿Acaso ángeles, oraciones, sacramentos? Algunos neoplatónicos habían recurrido a la Teurgia, a los Daimones, pero fueron a parar a los demonios, transfigurados en ángeles de luz. Porque las condiciones requeridas en un «mediador» entre Dios y los hombres eran muy especiales: tenía que ser igual a Dios e igual a los hombres, para poder mediar sin alejarse ni de Dios ni de los hombres. Ese mediador tenía que ser exclusivamente Cristo. Pero en las Confessiones se dejaba el problema simplemente esbozado dentro del «amor de Dios» a los hombres.

Y es que durante el presbiterado, Agustín había cambiado mucho al estudiar las Epístolas de S. Pablo a los Romanos y a los Gálatas. Podríamos hablar de una Reconversión de Agustín. Quería defender a toda costa la libertad humana, no sólo para denfender al hombre sino también a Dios. En efecto, si Dios «elige» a algunos hombres, habrá de tener algún motivo para elegir: elegir a ciegas no es elegir. Cuando en las Retractationes estampa la fórmula «Venció la gracia» da a entender que hubo una guerra y una agonía. Si Dios es justo, premia y castiga por algo, porque hay algún mérito o demérito (Retract. II, 1,1 PL 32,629). Esta fórmula parecía una confesión de que la herencia estoica y neoplatónica le había dejado en el fondo del alma un residuo pelagiano ante diem, que le obligaba a una «reconversión».

En efecto, ya no bastaba decir que el pecado original nos separa de Dios como si fuese una frontera, o una situación de rotura de relaciones. El pecado original traía consecuencias oscuras que pedían aclaración. La lucha con los maniqueos y especialmente con Fortunato, le había mostrado que la delectatio carnalis, no es un hábito griego, producido por la repetición de actos, sino que es causa de la repetición de esos actos. Tanto la ignorancia como la concupiscencia van tan adheridas al pecado original, que se pueden llamar «pecado». Y no son simplemente «situaciones», sino energías que nos empujan hacia el mal y nos alejan más y más de Dios, agregando pecados y pecados. ¿Cómo volver a unirnos con Dios? La tradición cristiana hablaba de la participación del hombre en la naturaleza divina, de una suerte de «divinización». Aunque Agustín utilizó una vez ese término, por influencias griegas, sin duda le repugnaba por su lucha contra el maniqueísmo, y contra la ilusión de poseer un Quid divinum, una substancia divina. La participación cristiana debería entenderse de algún modo muy especial, qưe venía ya señalado en el A. Testamento: la mediación era la «Palabra de Dios». Y esa misma palabra, con que Dios nos engendra no obra «mágicamente», sino por la virtud del mismo Dios. Dentro de la dinámica existencialista cristiana, Agustín iba creando un mundo de la Gratia Christi, para oponerlo al pecado y superarlo. La gracia cristiana tenía que producir una delectatio victrix, superior a la delectatio car- 
nalis. El texto Rom 5,5, que llamaba la atención de Agustín, creaba un nuevo modo de ser de la naturaleza humana cristiana. La Unión Hipostática que fundamenta el paso de lo visible a lo invisible, nos revela el sentido de la plenitud de Cristo: «De su plenitud hemos recibido todos, y gracia por gracia. Porque la ley fue dada por Moisés; la gracia y la verdad nos han llegado por Jesucristo» (Jn 1,16s). La gracia será pues también actual, como el pecado; una energía superior a la del pecado. Pero ésta es una nueva visión de la Cristología y de la Soteriología.

Agustín comenzó su tarea con tranquilidad, imponiendo los métodos de la fe, aunque reservó para la segunda parte de su obra el dar explicaciones racionales que, en realidad, eran un nuevo modo de repensar las fórmulas de la fe. Pero un extraño incidente puso de relieve el cambio que se estaba operando en él. Cuando había escrito los primeros libros de su obra, le fueron sustraídos por sus amigos curiosos y expectantes. El Santo se indignó hasta el punto de negar la paternidad a esos libros y pensó recoger la doctrina para refundirla en alguna otra obra diferente. Al fin se contentó con una corrección «con hacer lo mejor que pudo, (respetando la obra) no lo que hubiera deseado». Al estudiar este punto Plagnieux, concluye que las correcciones iban en el sentido de un Cristocentrismo progresivo (Cfr. PlagnieuX, J., Influence de la lutte artipélagienne sur de «De Trinitate», ou Christocentrisme de S. Agustín), en AM II, 817-826).

¿Por qué se indignó tanto Agustín ante ese incidente? No era al parecer demasiado grave, en cuanto que recuperaba los libros sustraídos. Lo que le indignaba era, pues, o bien el sentirse un tanto pelagiano, o el dar pie a los pelagianos para que abusaran de su texto, como lo hacían de otros libros de Agustín. Plagnieux da las razones en el mismo título de su estudio: estaba ya a la vista la polémica antipelagiana y esta nueva lucha, lo mismo que el Donatismo, implicaba una incorrecta o correcta visión de Cristo y de sus privilegios.

En las Confesiones dejaba ya el Santo testimonio de la «mediación» de Cristo, pero con brevedad. Ahora introduce una larga digresión en el libro IV del De Trinitate. ¿Entraba esa digresión en el esquema general? Para hablar del Hijo en el sentido de la «visibilidad» que proponían los arrianos no era necesario un capítulo tan largo sobre la «Mediación». Pero Agustín presentaba a la Stma. Trinidad como fuente de la espiritualidad humana y cristiana y por eso necesitaba analizar mejor la «mediación de Cristo». Los Padres Griegos estaban demasiado influidos por el platonismo y por el esencialismo griego, mientras que Agustín, según vamos viendo, se abría nuevos horizontes hacia el existencialismo cristiano histórico y temporal. Si comparamos a Agustín con el Areopagita o con Máximo el Confesor, comprobamos una diferencia sobre el papel de la Trinidad y de la Encarnación. La Trinidad no juega ningún papel en la espiritualidad y en la teología del Areopagita y de S. Máximo, 
mientras en Agustín la Trinidad es la fuente de toda la espiritualidad cristiana, en la mediación de Cristo (Cfr. U.v. Baltasar, «Patristik, Scholastik, und Wir», en Theologie der Zeit, 4 (1939) 65-134. Por eso en el De Trinitate no se trata sólo de combatir el Triteísmo y el Subordinacionismo, sino que el horizonte es cada vez más complejo.

A propósito de esa «mediación», el P. Goulven Madec nos presenta el diagrama que S. Agustín recoge de Platón (Madec G., «Diagramme augustinien» en Miscellanea di studi Agostiniani ni onere di P. Agostino Trapé Augustinianum XXV (1985) 79-94. Agustín parece hacer una confesión de «platónico», al establecer su problema: 1) hemos sido separados del Bien Inmutable; 2) pero no tanto que dejemos de buscar aquí en lo temporal la verdad, la eternidad y la felicidad: 3) Por eso se nos han dejado visa congrua, que nos adviertan que no está aquí lo que buscamos, pero que tenemos que regresar al lugar en que lo encontraremos (De Trinit. IV, 1,2 PL 42,887). Dios dispuso, pues, evitar nuestra desesperación, mostrando cuánto nos ama, y curándonos de nuestra suficiencia, mostrándonos que nos da la gracia, sin mérito de nuestra parte. En conclusión, «Cristo murió por nosotros» (Rom 5, 8-10) y «el Padre no perdonó a su Hijo» (Id. 7,31s (De Trinit. IV 1,1 PL 42, 887s). Y Cristo, quien como hombre recibió al Espíritu Santo, como Dios nos lo «envió», para «vivificarnos» y elevarnos.

El P. Madec se muestra excesivamente generoso con el platonismo de Agustín y no quiere entrar en las dificultades del problema, apoyándose en las mismas declaraciones de S. Agustín. Pero es preciso entender bien al Santo. Por de pronto tiene del platonismo un concepto falso, tomado del Lucullus de Cicerón (Ep. 1, PL 33,61s). Piensa que los platónicos aceptan un Dios cristiano, que es principio del ser, del conocer y del placer, y así merecen ser considerados como filósofos nobles ( $D e$ Civ. Dei, VIII, 9 PL 41, 233s). En tercer lugar, aplica a los conceptos platónicos sus propios conceptos, convirtiendo el platonismo en un almacén de materiales. Y por esta razón tuvo Agustín interés en proclamarse platónico, esperando que con algunas modificaciones, los platónicos podrían ingresar en el Catolicismo, como pudo esperarlo en el grupo platonizante de Milán. Sin embargo, cuando se trata de analizar el pensamiento de Agustín, es necesario enfrentarse con las dificultades. Es difícil hablar de un «diagrama» en Platón, ya que vive en un mundo estático y sincrónico, mientras que Agustín vive en un espacio diacrónico frente a la eternidad. (Cfr. Guitton, J., Le Temps et l'éternité chez Plotin et St. Augustin, Paris 1933). Es necesario reconocer las modificaciones que introduce Agustín. Para no extendernos con exceso, dejaremos al margen no sólo la «mediación» del alma humana, entre Dios y el mundo, sino también la historia de la Salvación según la cual vivimos aquí dentro de un régimen existencial (dispensatio tem- 
poralis). Nos limitaremos, pues a la tercera parte del diagrama, a la mediación de Cristo, que el P. Madec recoge en esta forma:

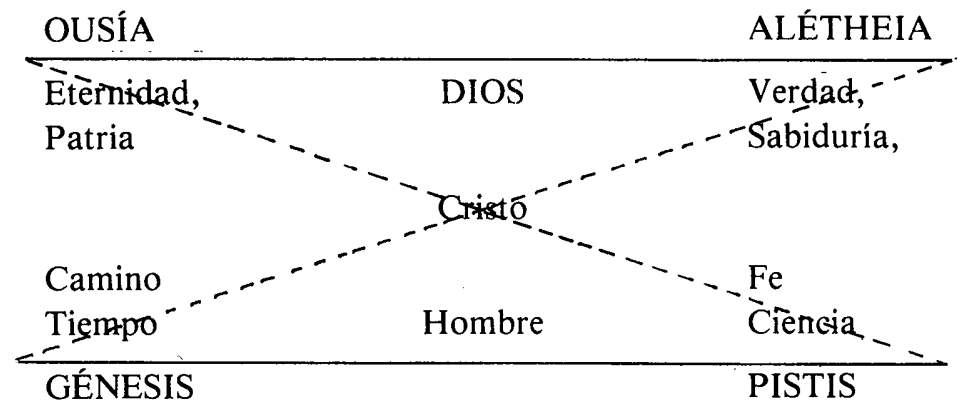

1. La Ousía platónica nada tiene que ver con la essentia agustiniana. Esta supone una creación libre, no una emanación necesaria y eterna. Aunque Agustín diga que los platónicos contemplaron «la Patria» desde lejos, esa Patria platónica no es la escatología cristiana.

2. Tampoco la Alétheia platónica es la verdad agustiniana. Platón no pudo resolver el problema de la verdad, ya que carecía de autoridad para aceptar e imponer la fe, que es la condición necesaria y el camino de la verdad (Crede ut intelligas). Por eso del Platonismo derivó la Nueva Academia con su escepticismo. Platón pretendía garantizar la «sabiduría» con el mito de la preexistencia y con el de la anámnesis: pero Agustín tuvo que renunciar a esos mitos, imponiendo su «iluminación» como participación en el Verbo.

3. Tampoco hay coincidencia en la Génesis, que en Agustín implica una creación, un tiempo evolutivo, un progreso, una historia, un Camino «portatil» que nos lleva a la Patria.

4. La diferencia más profunda se da en el terreno de la fe. Platón pretende a veces identificar la fe (Pistis) con la «recta razón», con la «recta opinión». Pero no cabe la «rectitud», cuando no es claro el punto de referencia. Lo que Agustín buscaba en la fe era la seguridad, la certidumbre, que Platón no podía darle con sus «opiniones» o «razones». Cristo; por ser la Autoridad divina que viene a nosotros es el mediador, que Agustín necesitaba. Así toma el platonismo como punto de partida para hablar de mediación, toma las columnas platónicas para construir una basílica cristiana y va corrigiendo de paso el «pelagianismo platónico». Convierte la filosofía en teología, y coloca al hombre en la «Miseria», no en el «Paraíso» (De Trinit. XIII, 1,1 PL 42,1014). 


\section{LA MEDIACIÓN DE CRISTO}

Agustín declara que la Encarnación no era necesaria. A Dios le sobraban medios para perdonar al hombre gratuitamente. O podía haber creado expresamente un hombre para unirle al Verbo, sin necesidad de tomarlo del linaje de Adán. Pero quiso la Encarnación en la forma concreta en que se verificó por motivos convenientes. No se trataba sólo de la iluminación mental, o de un Cristo gnóstico, sino de reconciliar con Dios a un hombre caído en una ignorancia y concupiscencia tales que reclamaba auxilios especiales. El hombre necesitaba ser «lavado por la sangre del Justo y por la humildad de Dios». Los platónicos reconocían la necesidad de una mediación, aunque la entendían mal, ya que el hombre era incapaz de purificarse a sí mismo y nadie fuera de Dios podía purificarlo.

Se trata, pues del hombre, pero del hombre pecador. Y el hombre ni siquiera puede conocer la malicia y fuerza del pecado sino es por la fe y por la revelación. La Encarnación satisface plenamente las condiciones que el hombre mismo pudiera desear. La Encarnación le hace comprender cuánto le ama Dios y cuán impío e injusto es el pecado. El Padre no perdonó a su propio Hijo, sino que lo entregó por nosotros, imponiendo así el concepto de «Redención». Por eso, a la manera que el pecado constituía no un simple fenómeno «moral» sino una situación metafísica y dinámica, que arrastraba a los hombres a la esclavitud, así la gracia de Cristo debía ser otorgada para liberar al pueblo de esclavos. La Encarnación del Verbo no sólo asumía a la humanidad para constituir una humanidad nueva, sino que tenía que convertirse en fuente de energía para superar el imperio del pecado con el poder divino.

Es verdad que la naturaleza humana es por sí misma «capaz de Dios», ya que el hombre fue creado para Dios (Fecisti nos ad Te) y el pecado original no borró del todo, sino que respetó las «reliquias» de la imagen divina. Pero la historia demostraba que eso no era suficiente para «redimir» al hombre de su esclavitud. Agustín había tenido que sustituir la «anámnesis» platónica por una iluminación apropiada y la participación platónica por una participación apropiada. La iluminación se había convertido en una participatio Verbi. Agustín se mostraba generoso con los filósofos, concediendo que habían conocido a Dios per ea quae facta sunt, aunque luego se negaron a darle gloria, y cayeron en la impiedad y en la injusticia. (De Trinit. XIV, 8,11 PL 42,1044). A pesar de esa concesión generosa de Agustín era evidente que S. Pablo reclama la necesidad de Cristo en la epístola a los romanos.

Por la Encarnación y su correspondiente kénosis, Cristo se convierte en el Médico, que cura nuestro orgullo fundamental y radical. Nos invita a abatirnos con Él hasta nuestro polvo para levantarnos luego con Él hasta su divinidad. Y luego se convierte en nuestro ejemplo, en nuestro modelo de santidad 
en este régimen temporal. De este modo puede surtir el cristianismo diferentes tipos de «mística de Cristo», como luego veremos. Por esas razones y otras muchas, convenía que el Verbo se encarnase en la naturaleza humana: ipsa natura erat assumenda quae liberanda. Además, este tema era muy interesante para Agustín, ya que la asunción de la humanidad de Cristo, sin mérito alguno de su parte, era el mejor argumento contra los pelagianos. Era un tema de la predestinación y al mismo tiempo un motivo por el que Cristo debe en cierto modo su gloria a nuestra miseria (De Vera Relig. 16,30, PL 34,135).

\section{MEDIACIÓN DIABÓLICA}

En realidad no hay paralelismo entre el «cuerpo del diablo» y el Cuerpo de Cristo, pues en el primer caso no hay cuerpo; se trata de un símbolo in figura principis Tyri. Sin embargo, las Reglas de Ticonio abrían hermosas perspectivas a la teología y mística de Agustín. Era evidente que el pecado original se había cometido bajo la sugestión del diablo y que en cierto modo el hombre quedaba a merced del diablo por su derrota, a juzgar por el Derecho militar romano. La lucha contra el maniqueísmo evidenciaba que la «sugestión» diabólica era algo más que una «sugerencia foránea»: llevaba consigo una suerte de presión impulsiva que horrorizaba a Agustín.

De todos modos, el diablo no servía para ser mediador entre Dios y los hombres a título de «dueño de la humanidad». Pudo ser mediador para la muerte «doble», es decir, para el pecado y para la corruptibilidad de la carne, para la muerte del alma y la del cuerpo. Pero como no podía ni morir ni resucitar, no podía tampoco ser un principio de vida y de resurrección: no podía ser mediador para la vida del alma y del cuerpo y tampoco podía serlo para la resurrección doble (del alma y del cuerpo). Pero la preocupación subsiste. La función del diablo no se limita a presentar objetos externos (visa), que puedan significar tentaciones o sugerencias por la malignidad subjetiva del hombre. El pecado original parece significar una situación objetiva, una energía objetiva, impulsiva, una inclinación al mal que limita y condiciona la libertad humana, aunque no la elimine. Es en cierto modo una raíz de la libertad, una raíz de la raíz y la delectatio carnalis revela un instinto oculto impulsivo. Es verdad que casi siempre eso proviene de una anterior repetición de actos, pero no siempre ni de igual modo. Hay muchos hombres que deploran su «falta de voluntad», confesando que no siempre «puede el que quiere», sino que muchas veces sólo «quiere el que puede». Agustín se maravillaba, al citar el texto bíblico concupivi desiderare (Ps. 118,20). En el caso de Judas, por ejemplo, Agustín entiende que «el diablo entró en Judas para moverle a entregar a Cristo con un impulso o moción, con una sugestión impulsiva» (De Gen ad litt. 
XI, 27,34 PL 34,443s). Ningún otro pensador antiguo aportó más a la psicología profunda. Cuanto más meditaba, más profundidades hallaba en el alma humana.

Algunos autores han hecho notar que Agustín exagera mucho los derechos militares del diablo sobre el hombre, como si Dios estuviese obligado a «pagar» un rescate en estricto derecho de justicia. Es verdad que la muerte de Cristo nos hace ver mejor la justicia de Dios y la malignidad del pecado. No hay que tomar la postura de Agustín con rigor, ya que es más bien un ejemplo o una comparación, un testimonio. El Santo insiste en que Cristo murió libremente, en que dio su vida libremente y en que nadie podía arrebatársela, ya que podía entregarla y podía reservarla. La dio por amor, en plena libertad. Pero imitando a S. Pablo, quiere también sacar partido para hacernos ver cuánto le costó a Cristo nuestro pecado. Así aprovechaba el concepto de «redención» de las religiones mistéricas; por una parte rechazaba a los maniqueos, haciendo ver la malicia del pecado y la justicia de Dios en la Cruz, y por otra rechazaba a los pelagianos, pues mostraba cuánto nos ama Dios aun siendo nosotros pecadores. No nos elige por méritos, sino a pesar de nuestros deméritos.

No debemos confundirnos cuando Agustín habla de manera que la misma concupiscencia parece ya un pecado, una segunda naturaleza. Es un resultado, como si dijéramos un vicio de construcción, una deficiencia constitutiva, que no tiene directamente carácter moral y libre, pero que significa la inclinación al mal, puesto que la libertad salió deteriorada de catástrofe original o natural, si buscamos pecados morales o ideológicos. La sugestión diabólica queda siempre fuera del santuario del alma humana; pero dada esa inclinación al mal que nadie puede negar, la sugestión parece algunas veces ya «eficaz»: parece ya una raíz negra de la libertad. No hay plena libertad si no hay plena información, si no hay conocimiento adecuado. Ahora bien, nacemos ciegos o semiciegos y nos endurecimos en nuestra ignorancia natural u original. El pecado original no consistió sólo en la sugestión del diablo, sino también en el orgullo del hombre que para ser «como Dios» trató de emanciparse, constituyéndose en fuente de sus propios valores.

\section{TEOFANÍA Y MISIÓN}

Agustín tenía ya resuelto el problema de las teofanías como visa congrua. Estaban encuadradas a la luz de la fe y de la tradición cristiana. No se pueden presentar en abstracto las alternativas: psicología o metafísica, filosofía o teología, etc., pues están explicadas desde el primer capítulo por la misma decla-

ración de Agustín. Él avanza hacia su propio campo, obligado por los concep- 
tos de creación, caída, predestinación, redención, gracia, gloria y unidad total. Las dificultades que va encontrando se deben a la misma polémica, a las circunstancias y a las relaciones. El método es siempre teológico y cristocéntrico.

Aunque todos conceden que su teoría de las teofanías y misiones representó un progreso teológico, algunos piensan que pagó un precio demasiado caro, ya que los Padre griegos acentuaban la acción personal y propia de las tres divinas Personas, mientras que no había peligro alguno de «triteísmo», (Dom Legeay, «L'Ange et les théophanies d'après la doctrine des Pères», en Rev. Thomiste, 10 (1902 y 1093). Otros, en cambio, con mayor rigor han visto que las razones y ventajas, que ofrecían el razonamiento y la exégesis de Agustín fueron la causa de su triunfo (no su autoridad) al eliminar de raíz, no sólo el peligro de triteísmo, sino también el de moralismo pagano, politeísmo arriano y subordinacionismo, manteniendo las orientaciones de Nicea y Constantinopla (Cfr. Lebreton, J., «S. Augustin, theologien de la Trinité. Son exégèse des Théophanies» en Miscel. Agost. Roma 1931, II, 822-836).

El problema de las teofanías estaba ya prácticamente resuelto para Agustín, en su refutación de los arrianos, al proclamar la consustancialidad del Hijo (Cfr. De Gen. ad litt. VIII, 27,50 PL 34,392; Epist. 167 y 168). Era normal que los términos latinos ofrecieran dificultades, como los habían ofrecido los griegos, en un misterio tan oscuro. Pero el sentido y la intención de los escritores eran claros, al contraponer el concepto de «persona» al de «naturaleza». Lo que verdaderamente interesaba a Agustín frente a los arrianos era la igualdad del Hijo con el Padre. Aprovecha, pues, la ocasión para insistir en el cristocentrismo:

Cum Mediator Dei et hominum, homo Christus Iesus, tradiderit regnum Deo et Patri, et iam non interpellet pro nobis Mediator et Sacerdos noster, filius Dei et filius hominis, sed et Ipse in quantum Sacerdos est, assumpta propter nos servi forma, subjectus sit ei, qui illi subjecit omnia... Quapropter cum Filius sit et Deus et homo, alia substantia homo potius in Filio que Filius in Patre. Sicut caro animae meae, alia substantia est ad animam meam, quamvis in uno homine, quam anima alterius hominis ad animam suam, (De Trinit. I, 10,20 PL 42,834).

Cristo conducirá a los creyentes a la visión beatífica y en esa contemplación será «todo en todos», como fin y término de toda buena acción temporal. Contemplaremos, pues a la Trinidad, conducidos por el Mediador. Durante esta vida temporal Cristo interpela por nosotros, y al final nos entregará al Padre, como reino adquirido por Él. Así en cuanto forma de Dios es tan invisible como el Padre y en la forma de siervo es el sacramento de Dios. Y puesto que la «misión» iba ligada a la teofanía, Agustín prefiere las más elocuentes: teofanía del Espíritu Santo en figura de paloma (misterio del Bautismo de Cristo), la del mismo Espíritu Santo en Pentecostés y sobre todo la Encarna- 
ción del Verbo. Aquí comienza Cristo su obra visible con nosotros y la terminará al juzgarnos justamente con el Padre y el Espíritu (Ibid. I, 13,28 PL 42,840 ss.). Los impíos verán, pues, la forma de siervo en Cristo, pero nunca verán la forma de Dios, pues nunca pasarán del sacramento (Ibid., n. $30 \mathrm{col}$. 842).

La doctrina de la teofanía o de la misión limita nuestra situación, al ofrecernos esos visa congrua y nada más. Los pelagianos querían ampliar horizontes con la fórmula ambigua gratia Dei in Christo. Esta gratia sería tan solo la gratia creationis aunque con una connotación ejemplar o doctrinal, ofrecida por un Cristo gnóstico. Por ello Agustín miraba a la Encarnación, a la gracia sobrenatural, y presentaba un régimen entero que llamaba «vivir bajo la gracia», un régimen temporal y existencial, de redención y de historia de la salvación (Ibid., IV, n. 7, col. 893). Dada la situación de pecado natural, los mismos ejemplos y doctrinas del Salvador hubieran sido insuficientes para alcanzar el grado de purificación que el hombre necesita en este mundo (Ibid. IV, 2,4 PL 42,889). Para alcanzar la unidad ofrecida por Dios, no basta la comunidad de naturaleza, sino que necesitamos la comunidad de la gratia Christi (Ibid. IV, 7,11 col. 896). Es necesario penetrar en las profundidades metafísicas del alma humana sobrepasando las ideologías morales.

La dialógica básica de Agustín es sencilla. El Padre es el principio sin principio, fuente originaria de todo bien. El Hijo es la Forma no formada, el formador, el reformador, que imprime su forma paterna en las criaturas, como imagen del Padre. De ese modo es Virtus et Sapientia Dei, principio ejecutivo y formal de la creación, y de toda criatura, individual o social. Es pues, la energía trófica, la potencia formativa del mundo. Y el Espíritu Santo es el lazo de unión entre el Padre y el Hijo, entre las criaturas y el creador. Los conceptos son aquí claros, aunque el lenguaje es con frecuencia muy complejo. Así muchos confunden el Espíritu Santo con la caridad o con otras funciones que solemos asignar al Hijo. Agustín en cambio, insiste en aspectos muy concretos. El Espíritu es el principio fecundante que en el principio palpitaba sobre las aguas. En concepto de «espíritu» da unidad al organismo vivo, incorpora orgánicamente al cristiano y a la iglesia, anima al cuerpo y así lo unifica y organiza en el tiempo y en el espacio.

Algunos autores reprochan a Agustín que su doctrina de la predestinación limita la redención universal, dejando al cristianismo un carácter relativo. Ya los pelagianos veían contradicción entre la "verdadera religión» y el cristianismo positivo. La objeción es demasiado amplia. Agustín tiene la ventaja sobre otros autores de mantenernos dentro del misterio.

Sorprende un poco que Agustín no haya formulado otro par de tríades en el terreno sobrenatural, como imágenes de Dios, para recapitular su pensamiento. En el terreno de la individualidad surge espontáneamente la tríade: 
Gracia-Delectación-Libertad. Así lo formula al narrar su propia conversión: «¿De dónde salió de pronto mi libre albedrío, para abrazar lo que antes odiaba? De la gracia» (Confess. IX, 1,1 PL 32,763). Del mismo modo en el terreno social podríamos formular otra tríade general: Gracia-Caridad-Unidad. La gracia de Cristo, en particular y en general, es el principio dinámico y espiritual que reunirá a la Humanidad hasta constituir la Unidad. La fórmula Christus Totus encierra el pensamiento agustiniano, que el Santo va desplegando ocasionalmente en sus interpretaciones exegéticas (In PS. 90,11,1 PL 37,1160 ) siguiendo y mejorando las indicaciones de Ticonio. Ticonio pensaba que sola la razón distingue las funciones que deben atribuirse a la Cabeza y a los miembros, y Agustín, aunque aduzca textos bíblicos, sigue esa misma indicación (In Ps. 140,3 PL 37,1817).

La unión de la Cabeza con el Cuerpo no es puramente moral ni puramente ontológica, como en el cuerpo humano físico. Son las dos cosas a la vez, y por eso es un misterio (In Ps. 142,3 PL 37,1847). A continuación Agustín anima a los fieles a considerar esa doctrina como si fuese un dogma central del cristianismo. Este Cristo total constituye así una sola Persona Mística. Pero ¿qué entendemos por persona mística? Agustín entiende que el Espíritu Santo tiene dos funciones en este Cuerpo: vivificar y reunir, como funciones propias del Espíritu y de la caridad (Sermo 142,7,7 PL 38,782). Así el misterio de la Iglesia va tan íntimamente ligado al misterio de la Trinidad que son inseparables (Sermo, 71,20,33 PL 38,463ss.). El Espíritu Santo constituye la sociedad, en cuanto Espíritu del Padre y del Hijo, y procede del Padre y del Hijo. Por eso la unidad de la Iglesia es también obra del Espíritu, ya que la Trinidad obra inseparablemente ad extra. Por eso insiste el Santo en la unción de Cristo por el Espíritu considerando que el mismo término Cristo significa «Ungido» (De Trinit. XV, 26,46 PL 42,1093).

En la relación entre ciencia y sabiduría, Agustín hace notar que sólo gracias a la Encarnación se hace creíble la felicidad eterna, y así las lucubraciones platónicas son mera veleidad (De Trinit. XIII, 11,12 PL 42,1025). Esta consideración le permite exponer otro aspecto del cristocentrismo. El discutir con los platónicos sería un problema sumamente arduo, ya que no nos ofrecen seguridad. En cambio la fe nos da tal seguridad que el problema queda resuelto por sí mismo. Quizá algunos privilegiados pudieron llegar a entender la inmortalidad del alma: pero como no pudieron comprender la eternidad auténtica, inventaron el problema de la metempsícosis (ibid.). Y si algunos rechazan esa teoría y dejan al alma separada del cuerpo, la declaran incompatible con sus teorías de la eternidad del tiempo y del eterno retorno (ibid.). 


\section{MísTICA DE LA CONTEMPLACIÓN Y MíSTICA DE LA CARIDAD}

«Hay que anteponer la necesidad de la caridad a la dulzura de la contemplación de la verdad» (C. Faustum XX 56ss, PL 42,435ss.). La gracia de Dios se derrama en nuestros corazones por el Espíritu Santo y produce las obras de benevolencia y beneficiencia, que consagran la perfección cristiana.

En este sentido, el P. Przywara habla elogiosamente del ethos agustiniano, que se contrapone al Oriente y que es denominador común de todas las Escuelas y Órdenes de Occidente desde la Orden de S. Benito hasta la Compañía de Jesús (Cfr. Przywara, E., San Agustín. Perfil humano y religioso, Madrid 1985). Pero ese ethos implica defectos. No se trata de un ethos, esto es, de una Ética, de una ideología moral, sino de una moral tan profunda que sobrepasa toda ideología. Así, la psicología profunda no es propiamente una ética racional. Esa «actitud espiritual», que puede llegar hasta las mayores profundidades de la mística, no se opone a la actitud oriental, sino por una modificación de la actitud. Agustín no renuncia al «interiorismo», pero relaciona la contemplación y la acción en forma original, imponiendo el primado de la caridad en el orden de la vida, no en el orden de la dignidad (Optimam partem). Przywara saca una gran ventaja de su postura, aunque insuficiente, pues nos da una visión más exacta de la mística cristiana, superando tantas discusiones inútiles, $\mathrm{y}$ centrando la atención en la participación del hombre en Dios mediante Cristo, rebasando los límites de la psicología y de la teología, y apoyándose en los textos más claros y definitivos de Agustín (De Trinit. XIII, 19,24 PL 42,1034; Ibid. XV, 26,46 col. 1095; Ibid. IV, 14,24 col. 901; Ibid. IV, 7,11 col. 895; Ibid. IV, 9,12 col. 896. Estima, pues que toda mística cristiana es una mística de Cristo y que todas las místicas de Cristo se reducen a la fórmula agustiniana: «Por Cristo hombre a Cristo Dios».

Como se ve, se impone una mística de «mediación», rechazando toda mística de acceso directo o inmediato a un Dios cualitativamente trascendente o a un Dios psicológico. Y la única mediación válida es Cristo. El grado ínfimo de esta mística sería la «mística nupcial», tan ligada al erotismo. Algunos autores estiman que esa «mística de Jesús» nace en la Edad Media con S. Bernardo. Sería temerario creer que los Padres ignoraron esta mística de Jesús que hallamos por ejemplo, en Orígenes y en S. Agustín. El grado sumo de esta mística sería la mística del Verbo, o participación en la iluminación mística del Verbo. Sólo que en ambos casos, como en todos los intermediarios y variados, la necesidad de la caridad es siempre reclamada por el régimen existencialista en que vivimos, y por ello la mística agustiniana será siempre «mística de la caridad». Fundamentalmente, como ya dijimos, esa mística viene preparada por la gracia de participación (Homo capax Dei) y por la participación en el Verbo (Illuminatio, participatio Verbi est) que tienen un desarrollo múltiple e 
indefinido. En este sentido, Przywara señala dos excesos: un exceso de confianza en el Mediador, y un exceso de distancia o desconfianza en el mismo. El primero viene regulado por la fórmula nupcial: osculetur me osculo oris sui, del Cantar de los cantares. El segundo viene regulado por la fórmula noli me tangere. La rectitud de la postura será la combinación de ambos principios, el de aproximación y el de distanciamiento, es decir, el de amor y el de respeto, evitando ambos extremismos. $\mathrm{Y}$ ya que esto puede aplicarse al individuo y a los entes sociales, podemos hablar de la «unión ontológica» de la humanidad con Cristo, diferente de la Unión Hipostática, desde luego, pero radical y mística: Unus homo in Adam, unus homo in Christo. Y por esto insiste tanto Agustín en el Reino que Cristo se gana para entregarlo al Padre, siendo menor que el Padre e igual al Padre (De Trinit. I, 8,16; I, 10,20 PL 42,834 y 835). Todo linaje de religión, interna o externa, implica de por sí un cristocentrismo. Las viejas tendencias mesiánicas del A.T. cobran en el cristianismo aspectos y fuerzas insospechados por los conceptos de encarnación, redención, intercesión y «entrega del Reino al Padre».

Aunque la originalidad de Agustín era clara desde el principio, la lucha pelagiana termina dándole un carácter muy singular. El ideal de unidad se logra por el ideal de caridad y el ideal de caridad ha de sobreponerse a un régimen de pecado: «Dame lo que me mandas y mándame lo que quieras». Dios tiene que auxiliarnos en todo lo que nos manda, y ese auxilio queda fuera del alcance de nuestra perspicacia, hasta que llega un momento en que nos preguntamos si se respeta realmente la libertad humana, o si las acciones humanas son realmente humanas. La actividad cristológica y eclesiástica van tan lejos.

El misterio es inevitable por la intervención del orden sobrenatural. Agustín no utiliza el término «sobrenatural» pero lo pone siempre de relieve al acentuar su gratuidad. Y sin embargo, nos hace ver que este hombre estaba hecho para Dios y que el pecado original no podía privar a Dios de sus derechos sobre el hombre ni al hombre de las reliquias de la imagen. $Y$ ésa es la paradoja: el hombre nada puede reclamar, pero puede mostrarse a sí mismo como imagen de Dios. Por eso los teólogos nunca terminarán sus discusiones acerca de la participación del hombre en Dios. Y de nada nos sirve el afirmar que a veces Agustín parece exagerado, ya que exagerado o no, tiene que sudar y sangrar ante el problema del misterio (Cfr. Przywara, E., Ringen der Gegenwart, Augsburg 1929, 545). Después de Agustín los pensadores han seguido discutiendo acerca del misterio del hombre en el mundo, pero el misterio sigue ahí haciendo frente a los más audaces sin entregar nunca su secreto.

$\mathrm{Al}$ estudiar el tipo humano o espiritual de Newman en la continuidad de la ascética y de la mística católicas, Przywara precisa los rasgos que unen a Agustín y a Newman en esa alternativa que se produce a lo largo de la historia 
entre una ascética y mística individuales y una ascética y mística sociales. En ese contraste incesante se aclaran los problemas de la mística agustiniana (Cfr. Przywara, E., Ringen der Gegenwart, II, Augsburg 1929, 871). La relación religiosa cristiana no se apoya en un antropocentrismo sino en un teocentrismo, si bien éste tiene que ser definido y concretado en Cristo. Dios es Luz y Dios es Amor, y el participar en esa luz y en ese amor, es participar en la naturaleza divina, en Dios mediante Cristo. Así podemos habitar en Dios y Dios habita en nosotros, y ésta es la esencia de la auténtica mística, como piensa Przywara (Ibid. II, 454). Siempre se tratará de una espiritualidad teocéntrica, no antropocéntrica. «Dios brilla en el rostro de Jesucristo, cuyo cuerpo es la Iglesia». El teocentrismo católico se produce tan solo «en Cristo».

Así llegamos a una conclusión inevitable: toda mística cristiana es una «mística de Cristo», pues siempre es un pasar de Cristo hombre a Cristo Dios. Ya se trate del Cristo bíblico, o del Cristo eclesiástico, ya se trate de una mística personal o de una mística cultural y social, ya se trate del Cristo kenótico o del Cristo Pantocrátor. Los tipos de mística pueden ser diferentes: mística de Cristo Esposo, mística de la Pasión, mística de la liturgia, mística del Logos, mística dela Eucaristía o mística de la noche de Dios en la faz de Cristo. Todos esos tipos cabęn justamente en la fórmula agustiniana «por Cristo hombre a Cristo Dios». En efecto, todos esos tipos de mística se realizan en el mismo Cristo, que es Dios y hombre, niño, crucificado y resucitado, Cristo esposo de cada alma y esposo de la Iglesia Una (Cfr. Ibid. II, 472).

\section{Yo SOY EL PRINCIPIO. EPÍlOGO}

Los platónicos introdujeron a Agustín en el concepto de Verbo, como «Principio». Pensaban que el comienzo del Evangelio de S. Juan debería esculpirse en el frontal de todas las Iglesias. Como por otra parte rechazaban radicalmente la Encarnación, se referían tan solo a la iluminación. Illuminatio participatio Verbi est (De Trinit. IV, 2,4; PL 42, col. 889). De un modo tan sencillo eliminaba el Santo los dualismos, maniqueos, donatistas y helénicos, para quedarse con un solo principio, puesto que Cristo dijo: «Yo soy el Principio, que hablo con vosotros» (Jo 8,25). Este punto de partida le servía para estudiar el tema de la creación, de la trinidad, del tiempo y de la eternidad, etc. Finalmente, frente a las tres hipótesis, elementos o principios platónicos, inherentes a la emanación, en la creación divina, como opus ad extra, sólo quedaba un principio: «el Padre por el Hijo en el Espíritu Santo».

El Padre es un Principium sine principio y el Hijo o Verbo es un Principium cum principio, y así el Génesis se traducirá: «En el Principio, esto es, en Cristo, creó el Padre (Dios) el cielo y la tierra» (Gen 1,1). Equivale al prólogo 
de S. Juan: «El Verbo era Dios. Todo fue creado por Él». Ya se ve que en la lengua latina, el término principium» conserva la condición del término archè en la lengua griega, para indicar «origen y expresividad». Bajo la influencia de la revelación bíblica, Agustín forja su propia teoría del ser, de la causalidad, de las potencias, de la forma y de la unidad que es la energía de la forma. Toma como modelo del ser el «ser vivo», no el ser muerto, como los griegos. El Principio indica, pues, la causa, la causalidad tal como se revela en el misterio de la creación. Esto da gran originalidad a Agustín. Le separaba un tanto de los Padres griegos, demasiado comprometidos con el clasicismo y con el esencialismo y resbala hacia un existencialismo inevitable.

La preocupación de Agustín por defender la libertad divina y la humana contra los maniqueos, le empuja en esa misma perspectiva de un Principio libre y creador, personal. La creación, el mundo, es pues, obra de la libertad. Rechaza la fórmula Deus creavit quia bonus, para aplicar la suya: Deus creavit quia voluit. Ese voluit no es un acto de voluntad, en el sentido en que lo entendía el hombre medieval, ya que la voluntad corresponde al Espíritu Santo. El voluit de la creación corresponde al Principio sin Principio, al Padre, a una orden imperial encerrada en la Palabra, en el Verbo. El Verbo significará, pues, la Palabra, el imperio, la intención, el sentido, pronunciado por el $\mathrm{Pa}$ dre. Por eso mismo se prefiere en griego el término Logos, con preferencia a otros términos semejantes. Logos anuncia la intención enérgica ya activa y al mismo tiempo su expresión, su expresividad.

Puesto que al decir, Principium Principio, aplicado al Verbo, estamos ya haciendo referencia a la creación, Agustín se acoge a la fórmula bíblica: Christum Dei virtutem et Dei sapientiam (1Cor 1,24). Pero la fórmula abre otros horizontes: viene a ser lo que llamaríamos principio eficiente y principio formal. El principio eficiente parece un principio ejecutivo, y Agustín lo describe pintorescamente: un padre entrega a su hijo el plano de una casa para que la levante y el plano es el mismo hijo, en cuanto Verbo, en cuanto Palabra, intención o sentido del Padre. Y acontece entonces algo que se repite en Agustín. $\mathrm{El}$ «mundo» se nos convierte en una creatio continua, producido in $i c t u$, en un instante. La creatio continua no significa que el mundo sea una pura actividad creadora de Dios, ya que hay que distinguir la creación de la conservación y administración del mismo mundo. Por otra parte, si quisiéramos recurrir en Agustín a una «evolución», no hallaríamos en él elemento alguno científico. Llamamos, pues, creación continua a este mundo, cargado de «razones seminales», que irán apareciendo y desarrollándose en el tiempo según las circunstancias, pero dirigidas por ese principio interno en un sentido concreto que las circunstancias no pueden fijar.

Es claro que así se distingue de los demás Padres por su dinamismo y existencialismo. La misma gratia Christi ha de ser un principio dinámico, esto es, 
no se limitará a borrar los pecados del mundo, sino que vendrá a promover el progreso y la luz del mundo. La fuerza del principio crítico será pues: «Dixit Deus fiat lux et facta est lux. La palabra conserva el prestigio de los tiempos de la magia, aunque ya no como magia, sino como virtud divina, como intencionalidad divina. La palabra es el semen, el principium coniunctum de la generación del Verbo y también de nuestra filiación divina, pues fuimos engendrados ex Deo: genuit nos verbo veritatis.

Teilhard de Chardin ha insistido en este aspecto positivo del principio crístico, que no sólo realiza la redención, sino que es la luz del mundo $(\operatorname{Jn} 9,5)$. Él es el principio de la unidad, la energía de la unidad que irá poco a poco unificando el mundo hasta la edad de la plenitud de Cristo $(E f 4,13)$. El mundo salió de la unidad, progresa por la energía de la unidad y culminará en la unidad terminal. Es pues normal que la Biblia recogiera las doctrinas de la preexistencia de Cristo, independientemente del pecado original. Se presenta como principio, no sólo antropológico, sino también cósmico. Las fórmulas de Agustín son a veces paradójicas, pero ya no sorprenden: por ejemplo: « $i \mathrm{Oh}$ feliz culpa, que nos mereció un tan excelso Redentor!». Cristo no sería Redentor si no hubiese pecado Adán, pero en el cuadro de la predestinación estaban ya Adán y Cristo como tipo y antitipo previstos. Aunque a veces se presenta al Santo como representante de un mundo regresivo y pesimista, basta hojear la Ciudad de Dios, para ver como progresamos hacia un Juicio final, bajo un principio divino. En el clasicismo, el Logos era proclamado Déuteros Theós, y su unificación resultaba imposible por la necesidad de la emanación, y del esencialismo. Pero se extendía la física todo lo posible, inclusive a la «metafísica», para identificarla con la «realidad». En cambio en el cristianismo era posible reducir la Stma. Trinidad a un solo Principio en el sentido en que nos lo explica Agustín. Y en eso consiste el cristocentrismo universal, que destaca, como primer rasgo del Verbo la «iluminación (Illuminatio participatio Verbi) y como segundo rasgo la Encarnación.

\section{PRINCIPIO ANTROPOLÓGICO}

Dentro del método general agustiniano, el principio cognoscendi precede al principium essendi. La Encarnación debe preceder a la razón, y entenderse en sentido riguroso y absoluto. Así queda favorecida la articulación entre la Revelación y la Encarnación del Verbo en el plan de Dios y en una Historia de la Salvación. Sin embargo, este lenguaje es demasiado abstracto, ya que los textos bíblicos pueden ser interpretados o actualizados con mayor o menor libertad racional. Y concretamente Agustín dio pruebas de una inmensa libertad racional en la exégesis personal, según las circunstancias. $Y$ así vemos de 
hecho las dificultades que tanto los primeros cristianos como Agustín encontraron en la doctrina de Cristo, dificultades que se marcaron en las herejías cristológicas y se siguen marcando hoy en los mil ensayos de cristología. Todos parten de la revelación, de los mismos textos y llegan a resultados muy diferentes.

Se denuncia a san Agustín y a los Padres en general de haber atendido con exceso a la naturaleza divina de Cristo, para interpretar luego tanto el lenguaje como la doctrina según sus gustos. Por eso surgieron las herejías cristológicas. Aun así, los conceptos de naturaleza, persona, Unión hipostática, etc., contribuyeron a iluminar en gran manera la mente humana. Modernamente las cosas han ido de otro modo, pero a la vista están las angustias que nos ofrece la cristología actual. Siempre hubo maneras de interpretar a Cristo, pero hubo una época en que comenzaron a escribirse "Vidas de Cristo", tomando los Evangelios como fuentes históricas científicas. Después vinieron las críticas hasta llegar a la historia y prehistoria de las formas, a unas teologías bíblicas más o menos filosóficas y un biblicismo positivista que degenera en capricho, o pasa por alto toda la filosofía y la teología. Naturalmente la exposición histórico-crítica de los modernos no puede compararse con la alegre manera de hacer de los Santos Padres, pero nos permite ver que siempre hubo abusos y que el problema es muy profundo, un auténtico misterio.

En todo caso hay un rasgo que caracteriza con frecuencia a los pensadores cristianos y que se nos revela con fuerza en la crisis actual. Si comparamos la Teología dialéctica de $\mathrm{K}$. Barth con la Teología liberal, y aun con la Teología católica, encontramos un rigor que parece distinguir todas las posturas. La influencia de Lutero persiste aprovechando todos los recursos de la razón para denigrar a la razón. Y en este sentido, Agustín, no sólo respeta los supuestos derechos de la razón humana, sino que busca en todo lo posible la armonía y síntesis de la razón y revelación. Y eso no sólo cuando se debate en el orden natural, sino también cuando comenta el orden sobrenatural. En ambos casos introduce toda la luz que encuentra, venga de donde venga. En todo caso, dentro del misterio de la predestinación, Dios llama a las cosas que son como a las que no son.

Ni la razón ni la revelación nos permiten separar el principio antropológico del principio cósmico. El hombre no es un ser independiente, que se desarrolla diacrónicamente en la tierra, fuera de la física. Y esto se aprecia con mayor fuerza cuando relacionamos el concepto de predestinación con el de Encarnación. El pensamiento orgánico de Agustín le obliga a aplicar al orden sobrenatural la dialógica del orden natural. Es verdad que el hombre natural nace de la sangre y de la voluntad del varón, mientras que el hombre sobrenatural, adoptado por Dios, nace ex Deo, quia genuit nos verbo veritatis (Sant $1,18)$. Pero nunca podemos separar al hombre natural del sobrenatural como 
si fuesen dos hombres diferentes. Y san Agustín es un caso especial de unión entre el orden natural y el sobrenatural, pues parece que el primero es deficitario, para reclamar la ayuda del segundo. En esto consiste el llamado pesimismo agustiniano.

No podemos ser hijos naturales de Dios. Tampoco bastaría ser hijos adoptivos, como mera fictio iuris, como flatus vocis. Sólo nos queda ese misterio que se revelaba ya en la etimología de la voz mística (myo). En el hombre concretamente se revela un principio antropológico, no diferente del cósmico, pero característico de un mediador entre Dios y los hombres. Al mismo tiempo se nos revelan dos tipos de mística, una natural y otra sobrenatural, que se identifican y reúnen en Cristo. La mística de la fe será transformada en mística de la visión beatífica, ya que por Cristo vamos a Cristo, y por la ciencia de Cristo vamos a la sabiduría de Cristo. Así oponía Agustín a Cristo-Camino al camino de Porfirio. En Agustín el Camino es ya un principio antropológico que nos lleva por el camino temporal a la eterna. Cristo es, pues, camino en ambos órdenes, en el natural y en el sobrenatural, porque no es sólo la iluminación sino también la redención, el sol de las inteligencias y el manantial de la fe.

Se explica así por qué Agustín habla de un modo a los donatistas y de otro a los paganos. A los primeros se los combate con la Biblia en la mano, porque ellos la admiten y no tiene otro criterio. En cambio los paganos y pelagianos (griegos) piden inteligencia. Y, sin embargo, el tiempo ha de quedar subordinado a la eternidad, la ciencia a la sabiduría, la fe a la visión. Pero la fe y la visión no son dos carriles paralelos, que nunca se vayan a encontrar, sino que se encuentran y se complementan sin cesar. Por ejemplo, Agustín expone a los donatistas que el Padre «prometió a su Hijo el rebañico de los predestinados», pero luego les expone que les prometió como herencia todo el género humano, todos los pueblos. Esa herencia o pueblo deberá devolverlo al Padre el Hijo, después de su reconquista. Así Agustín se encuentra con una intención salvífica universal y con una limitación relativa y así no puede evadirse del misterio. Por eso Agustín entendía el donatismo como «problema de Cristo», con mayor profundidad que los donatistas, psicólogos, sociólogos, historiadores y políticos.

He ahí por qué maniqueos y donatistas temían a Agustín: los transportaba fácilmente a unas profundidades que no podían entender, según las circunstancias.

Si comparamos nuestra situación bíblica con la de los Santos Padres y aplicamos la distinción entre el Cristo de la Historia y el Cristo de la fe, y pensamos en la desmitización ideada por Bultmann y en las limitaciones antes marcadas, comprenderemos que a nosotros nos estén vedadas esas construcciones espirituales grandiosas y alegres que hallamos en los Santos Padres y 
concretamente en san Agustín. Sólo cabe que seamos capaces de comprenderlos a ellos en el ambiente y circunstancias en que vivían, «en su situación». Y de eso se trata en el presente caso, de la magnífica libertad con que Agustín armoniza y acompaña las fórmulas de san Pablo.

Algunas obras debieron ejercer una fuerte influencia en el Santo, como, por ejemplo, las Reglas de Ticonio. Agustín no las acepta íntegramente. Dirigen la atención hacia el punto interesante del Cuerpo de Cristo y de los diferentes cuerpos de Cristo, para configurar el Cristo total (De doctrina christiana III, 30,42: PL 34,71ss). Ticonio busca una clave exegética, mientras que Agustín busca una construcción teológica. En la Regla tercera vemos cómo esa influencia de Ticonio venía ya amenazando en las manos de los pelagianos.

El conflicto entre la ley y la gracia, entre el deber y el placer, entre la delectatio carnalis y la delectatio victrix, la necesidad de un auxilio que nos libere de la tendencia al pecado, dejan ver a Cristo como principio actual y toda acción divina como acción cristológica y eclesiástica. La doctrina de los sacramentos se extiende a todo el pensamiento orgánico. "Vivir bajo la gracia» es ya un régimen total. La necesidad del Mediador se coloca en el centro de la vida humana. Y no sólo en el sentido de aquella esfera platónica, cuyo centro es Dios y cuyos radios somos nosotros, sino en el sentido existencialista y dinámico del sine me nihil potestis facere. Ya se sobreentiende que tanto en el orden natural como en el sobrenatural caben múltiples distinciones. Pero precisamente por eso tiene Agustín sus normas para uno y otro orden, su filosofía y su teología. Así el cristocentrismo cobra un aspecto casi nuevo, por su extraordinario desarrollo y por su dinamismo.

«Los que me dio el Padre». Si los platónicos preferían la metáfora del «regreso de las almas a la patria», para definir la situación del hombre en el cosmos, los predestinacioniatas preferían la fe en una elección privilegiada de Dios. En ambos casos era fácil adivinar la fórmula mítica. La salvación universal se obtenía agregándose a la Filosofía o a la Sinagoga. Pero en Israel la voluntad salvífica universal de Yahvé comenzó a revelarse en el destierro de Babilonia (Deuteroisaías) como alternativa con el nacionalismo sagrado. El libro de Jonás es un alegato pintoresco. Los cristianos, al destruir la muralla que separa a ambos pueblos, gentil y judío, pasaban fácilmente por encima de las alternativas, preocupados por otros problemas más acuciantes. Si hubiésemos apretado a san Agustín, preguntando qué prometió Yahvé al Mesías o el Padre al Hijo, replicaría al momento: dabo tibi Gentes haereditatem tuam et possesionem tuam terminos terrae» (Ps 2,8). Y esto se lo diría concretamente a los donatistas cismáticos. Nos preguntamos pues, qué límites puso el Padre a la herencia de su Hijo, ya que además del núcleo central, queda una posible añadidura de salvación, como en Grecia o en Israel. Y no cabe duda sobre la 
persuasión fundamental de Agustín en su argumentación. Como entendía el cardenal Newman, securus judicat orbis terrarum. En ese sentido fue cobrando carácter el término "catholica», con que fue designada la Iglesia.

Al combatir el subordinacionismo arriano, Agustín no tiene más que distinguir las dos naturalezas de Cristo (De Trint. I, 8,15 PL 42,829). La naturaleza humana de Cristo nunca será sustancia divina: por ende, cuando Cristo entregue o devuelva al Padre el Reino conquistado, se lo entrega a sí mismo: en cuanto hombre se lo entregará a Dios, a la Trinidad. El Cuerpo de Cristo es el número de los predestinados. (De Trinit. I, 7,14 PL 42, col. 828), pero estamos ante un misterio. Los grados de participación en Cristo son muchos y todos contribuyen al organismo sagrado, como subsistirá eternamente: tales nos amat Deus, quales futuris sumus, non quales sumus. Quales enim amat, tales in aeternum conserva (Id. 21, col. 835).

La dificultad es grave, pero los tiempos de Agustín no son los nuestros ni nuestra situación es la suya. Él aceptaba con los maniqueos la doctrina de la predestinación, pero les reprochaba el mantener eternamente un dualismo, que no puede ser reabsorbido por el Principio del Bien. La objeción podía aplicarse a los donatistas, pelagianos y filósofos. Por otra parte, debía tener precaución con las doctrinas de la apokatástasis, tomada por Orígenes de la Metempsícosis, para ir volatilizando el mal del mundo. Pero el cambio de actitud del Vaticano II nos demuestra que «aún hay mucho que heñir» Dios es el creador del cielo y de la tierra, que hizo al hombre a su imagen y semejanza. La literatura sapiencial, las influencias helénicas y de los «Misterios», el ambiente de los amigos de san Pablo en la diáspora, dejaban abiertas muchas perspectivas dudosas que aún hoy nos intranquilizan.

También dentro del cristianismo corremos el riesgo de aplicar la fórmula extra ecclesiam nulla salus con un rigor tan grande como el de los fariseos, equiparándonos a Dios, olvidando que nuestra ciencia es Cristo y nuestra sabiduría es Cristo, considerándonos privilegiados. Curiosamente, aunque Agustín subordina la ciencia a la sabiduría, al aplicar a Cristo el método de la revelación, comienza estableciendo el prólogo de san Juan y así se invierten los términos: la historia y la crítica quedan subordinadas a la eternidad y a la sabiduría, ya que la participación en el Verbo, la iluminación, es la que ha de dar sentido universal a los textos bíblicos, dentro del plan de Dios. Aunque ahora vivimos de la fe y terminaremos en la visión, la visión es la que da sentido a la fe (De Trinit. XIII, 1,1: PL 42, col. 1013).

En este punto, Agustín sigue su norma general. La fe es un fenómeno psicológico: es una percepción experimental, una vivencia, que supera el escepticismo de facto. Si yo digo que creo, afirmo dos cosas indiscutibles. Cuando a mí «me parece» que tengo fe, es inútil que nadie me lo discuta. Aunque yo no tuviera esa fe en los textos bíblicos, mi convicción es indiscutible. Yo puedo 
creer que tengo fe con ciencia cierta y con evidencia sincera (Ibid. 2,3, col. 1014). Además, puedo distinguir la fe de la credulidad, esto es, cuándo mi fe es recta y cuándo no lo es. En este sentido es claro que la fe precede a la visión y a la sabiduría. Porque en primer lugar es un deber que se revela inicialmente a la conciencia: Nemo crederet, nisi viderit esse credendum. En segundo lugar es una consciencia psicológica evidente. En tercer lugar admite una serie de criterios de rectitud para distinguirse de la credulidad: hoy los llamamos motivos de credibilidad. Y en cuarto lugar, es el método establecido por la Providencia en nuestra situación de régimen temporal.

Pero la subordinación al Verbo-Sabiduría es también clara. En primer lugar se trata de una intención inicial: intellige ut credas. En segundo lugar, en el terreno de la fe nunca llegaremos a la evidencia completa de la persona que nos ofrece el mensaje ni a la evidencia del mensaje o contenido del mismo. Por eso la fe es un «yugo del alma»; por eso la fe es meritoria, ya que supone una determinación libre, como dicen algunos, "dar un salto en la tiniebla». $Y$ en fin, el plan de Dios está concebido ut videant no ut credant: crede ut intelligas definitivamente.

No es pues suficiente conocer bien la Biblia, recopilar, ordenar y sustanciar bien los textos bíblicos para conocer a Cristo. Ni basta una Teología bíblica o una Historia de la Salvación, si no van ligadas al eterno plan de Dios. Sólo el Verbo da sentido a la historia, no a la manera de las pretensiones de los griegos o de Hegel, empeñados en una filosofía de la historia, sino dentro de una teología de la historia. Porque una filosofía de la historia es determinada por la necesidad, mientras que la libertad divina y humana son necesarias para una historia verdadera.

Algunos autores critican a Agustín como si él provocara los conflictos, cuando los conflictos son objetivos. ¿Cómo concordar la soberanía divina con la autonomía humana? ¿Cómo explicar los hábitos, no como repetición de actos, sino como acto previo? Eso acontece en el presente caso y con mayor motivo, ya que no sólo contienden la revelación y la razón, sino que ambas contienden consigo mismas, y dentro del «misterio» es inútil contender. ¿Cómo es posible la unión con Dios, no ya sólo en la Unión Hipotática, sino también en la unión mística? Todavía hoy, cuando los límites de nuestro conocimiento se han roto y nos vemos forzados a reconocer nuestra ignorancia en todos los terrenos y el misterio nos rodea por todas partes, nos queda una cierta facilidad para ser humildes. Pero los antiguos, en su simplicidad, se creían dioses a cada nuevo y parcial descubrimiento y así hablaban con una increíble libertad. Y cuando ya no podían esclarecer la situación, se contentaban con aceptar la realidad, como razón suprema. Eso acontecía a los cristianos en el orden de la fe, ¿Por qué cree éste y no áquel? «Creyeron los que estaban preordenados a la vida eterna» (Act 13,48). 
También es verdad que hoy podemos comprender mejor a Agustín. Hoy entendemos que el problema de «la raíz de la raíz» que Agustín utilizaba contra los maniqueos como una chaza es un problema gravísimo. Freud nos hizo ver que las profundidades del alma condicionan nuestra libertad con una fuerza y extensión que ignoramos. El carácter impulsivo del inconsciente nos deja perplejos. No nos sorprende el hombre que dice: «Yo quisiera querer, pero no puedo", como preconizaba san Agustín. Los conflictos son, pues, objetivos, y están ahí.

Sin embargo, Agustín no niega la libertad humana. Cuando se le acusa de determinista, a pesar de su negativa explícita (v. gr. Max Scheler), se incurre en el sofisma de adoptar una postura previa; dejan a un lado el compromiso de la revelación, caen víctimas de la dialéctica o se entregan al capricho racionalista de los pelagianos. Es claro que la oposición del Dios de Abrahán al Dios de los filósofos, tal como la entiende Pascal, es un enfado pueril contra el «misterio», ya que el Dios de Abrahán, Isaac y Jacob es el Dios de Platón, Aristóteles y Plotino. Los tres grandes filósofos, iluminados por el Verbo, participaron en él más intensamente que los demás hombres. Precisamente cuando Agustín expone la fórmula "Yo soy el que soy», no la aplica al Dios de la fe, sino al Dios de la inteligencia. Así el Verbo es quien ilumina para conocer al Verbo en Dios. Y por eso dice Agustín que cuando Cristo devuelva al Padre el reino que éste le consignó como herencia, se entrega el Reino a sí mismo, pues él es Dios. Y esto consiste simplemente en la transformación de los "cristianos", ya que todos son cristianos de algún modo: pasan del régimen de la fe al régimen de visión beatífica, de la miseria al paraíso. La lucha que san Pablo y sus amigos de la diáspora sostuvieron para contrastar el cristianismo frente al judaísmo, es un problema muy difícil que todavía hoy subsiste. Dios bendecía a Abrahán principalmente. Pero luego, por medio de Abrahán, bendecía a todos los pueblos de la tierra. Y quizá ése era el sentido, no sólo del cristianismo sino también del judaísmo.

\section{EL SACRIFICIO PERFECTO Y EL SACRAMENTO PERFECTO}

En la' Confesiones Agustín quería fijar las condiciones de un sacrificio perfecto de reconciliación del hombre con Dios. Para eso acoplaba el concepto de Mediador perfecto al de sacrificio perfecto, ya que el Mediador ha de ser Dios y hombre y el sacrificio ha de participar de ambas condiciones. En el De Trinitate se marcaban esas condiciones con fuerza: sustancialmente la víctima ha de ser un Hombre-Dios, Cristo. Pero mientras la divinidad de Cristo queda siempre invisible, su humanidad visible debe entrar en el espíritu invisible para tener eficacia. Así el hombre se incorpora al Cuerpo de Cristo. Y de este mo- 
do, incorporarse al Cuerpo de Cristo significa incorporarse a los «signos» del Cuerpo de Cristo, a la Iglesia y a la Eucaristía, sacramentos de Cristo. «Cuerpo de Cristo» significa la alternativa que se mantiene en las demás metáforas paralelas y semejantes: hombre exterior e interior, esposo y esposa, cabeza y cuerpo, carne y espíritu. La caridad aglutina el organismo de la fe, y el Espíritu Santo unifica ese organismo, constituyendo la misma unidad de fe orgánica.

Se abre y plántea aquí el problema complejo y profundo del Cuerpo Místico como sacrificio perfecto de reconciliación y satisfacción. Porque cada cristiano tiene su valor propio y personal y penetra en un organismo común para vivir «en él», esto es, para sufrir y gozar con él, participando en el dinamismo del Mediador, en el Arché de Cristo. Esto significa no sólo acoplar el tiempo a la eternidad, sino también reunir los métodos que los críticos buscan en Agustín: la teología se une a la filosofía, la metafísica se une a la historia, la razón a la revelación. Pero esto acontece en una profundidad, que es una lejanía ideal, ya que Agustín se ha ido apoyando en conceptos cada vez más profundos y sutiles. Ésta parece la razón de que vuelva siempre contra la teurgia de los platónicos, para poner de relieve la «Mediación de Cristo». El problema quedaba planteado en el camino de Damasco: «Saulo, Saulo, ¿por qué me persigues?». Cuando el cristiano es perseguido, Cristo es perseguido. San Agustín, pues, tomará ese texto como punto de partida: El cristiano es perseguido en Cristo y Cristo es perseguido en los cristianos. Además, san Pablo apuntaba una teoría de «la pasión del Apóstol». El Apóstol de Cristo sufre en medio de la comunidad cristiana, participando en la pasión de Cristo e invitando a Cristo a participar en la pasión de la comunidad y del apóstol. Y se trata aquí de una «unión mística», si tomamos el término místico correctamente y no a capricho. No es pues extraño que san Agustín, aquí y allá, según le salen al paso los textos, los utilice con su ordinaria libertad como el perfecto sacrificio del cristiano en el organismo del Cuerpo de Cristo. De ese modo la actividad cristológica y eclesiástica se va extendiendo a todas las actividades humanas, individuales y sociales, victorias y derrotas, alegrías y tristezas.

Al acabar la II guerra mundial, circularon por Europa algunos escritos impresionantes que describían la persecución de las «Iglesias del silencio». Cristo iba de una nación a otra, arrastrando su cruz, apaleado, escupido, azotado, abofeteado. Especialmente de Polonia llegaban cartas impresionantes. Por su parte, Teilhard de Chardin celebraba en las montañas de China una suerte de misas espirituales, en que se recogía esta doctrina de la comunión de los santos. El sacerdote ofrecía en la patena y en el cáliz las alegrías y los dolores de la humanidad como sacrificio perfecto de los cristianos. La doctrina era tradicional, pues siempre se habló en la Iglesia de que toda pasión es un «padecer con Cristo», que es un «padecer en Cristo», porque yo estoy en Cristo, pero también porque Cristo está en mí. 
En los últimos tiempos se han multiplicado los estudios teólogicos acerca de la Iglesia como «sacramento de Cristo». Obligaba a ello la nueva presentación de la sacramentología. Más aún, algunos teólogos desean reducir el cristianismo a un misterio y la teología a una sacramentología. Sin duda que hemos perdido el sentido de la Eucaristía tal como la vivían los primeros cristianos, pero una renovación del fervor eucarístico traerán consigo sin duda una renovación del fervor religioso y cristiano. Y la forma grandiosa de esa concepción será el cristocentrismo, de cuius plenitudine omnes nos accepimus et gratiam pro gratia. Agustín fue mal interpretado. Primero se opuso un realismo grosero a un simbolismo grosero, que apenas tocaban el problema. Después la reducción escolástica puso por doquier un fisicismo helénico. ¿Quién podía entender que Cristo es el «sacramento del Verbo»? ¿O que la Iglesia visible era el sacramento de Cristo, o que la Eucaristía era el sacramento del Cuerpo Místico? ¿O quién podía comprender el misterio que se encerraba en el «comulgar»? Aún hoy esa doctrina de los «Misterios» es tan profunda que se hace casi imposible de entender: durus est hic sermo. ¿Qué sentía un iniciado, cuando caía sobre él la sangre de la taurobolia y se sentía identificado con su «ídolo», con su Dios? ¿Qué sentía o qué siente un judío piadoso cuando celebra el memorial de la Pascua como una celebración de presente, como una «re-presentación»? Como se ve, este misterio afecta profundamente a la «verdadera religión» y es uno de los pilares de la doctrina cristiana.

LOPE CILLERUELO

Estudio Teológico Agustiniano

Valladolid 